Volume 3, Nomor 1, 2020, hlm. 71-92

P-ISSN: 2622-2280 | E-ISSN: 2622-4658

https://ejurnal.iiq.ac.id/index.php/alfanar

DOI: 10.33511/alfanar.v3n1.71-92

\title{
Sejarah dan Perkembangan Penulisan Tafsir Al-Quran di Madura
}

\author{
Ulfatun Hasanah \\ UNUSIA Jakarta \\ ulfahannaahmed@gmail.com
}

\begin{abstract}
:
The attention of Madura's Scholars to the Qur'an not only ceases to teach the correct and eloquent reading of the Qur'an, but continues to the understanding of the verse content. This is evidenced by the existence of several works in the study of the Qoran that developed in Madura, both in Madurese, Indonesian, and even Arabic. Historically, the genealogy of Tafsir in Madura began with the discovery of the Qoranic translated by Khalil Bangkalan in the 1900s. After Khalil's era then grow the work of interpretation with a variety of forms and variants, ranging from oral interpretation, interpretation based on certain suras in the Qoran, to a complete interpretation of $30 \mathrm{Juz}$. This indicates that the development of Qoranic Interpertation in Madura continues to progress from time to time. This paper will explain comprehensively the history and characteristics of the interpretation in each period, starting from the form, method, to the style of interpretation in Madura. In addition, it also explains the behavior of the Madurese people towards their contact with the Qur'an, since the early Islamization era in Madura.
\end{abstract}

Keywords: Interpretation of the Qoran, Translation, Madura Language

\begin{abstract}
Abstrak:
Perhatian ulama Madura terhadap Al-Qur'an tidak hanya berhenti pada sebatas mengajari membaca Al-Qur'an yang benar dan fasih, melainkan berlanjut pada pemahaman terhadap kandungan ayat. Hal ini terbukti dengan adanya beberapa karya dalam kajian Al-Qur'an yang berkembang di Madura, baik berbahasa Madura, maupun bahasa Indonesia, bahkan bahasa Arab. Dalam sejarahnya, geneologi tafsir di Madura dimulai dengan ditemukannya Al-Qur'an terjemah antar baris karya Syaikhona Khalil pada tahun 1900-an. Pasca karya kiai Khalil ini kemudian tumbuh karya tafsir dengan beragam bentuk dan varian, mulai dari tafsir lisan (the oral interpretation), tafsir bedasarkan surah-surah tertentu dalam Al-Qur'an, hingga tafsir yang lengkap $30 \mathrm{Juz}$. Hal ini menujukkan bahwa perkembangan tafsir di Madura terus mengalami kemajuan dari waktu ke waktu. Tulisan ini secara komprehensif akan menjelaskan sejarah dan karakteristik dari tafsir di masingmasing periode, mulai dari bentuk, metode, hingga corak tafsir di Madura. Di samping juga menjelaskan tentang perilaku masyarakat Madura terhadap persinggungannya dengan Al-Qur'an, sejak masa islamisasi awal di Madura.
\end{abstract}

Kata Kunci: Sejarah Tafsir Al-Qur'an, terjemah, bahasa Madura 


\section{PENDAHULUAN}

Sebagian besar karya kesejarahan yang ditulis peneliti Indonesia berkisar pada halhal yang 'istimewa', seperti tokoh-tokoh berpengaruh, peristiwa besar, dan pusatpusat perkotaan. Sebaliknya, hal-hal yang 'biasa' tidak mendapatkan jatah secara layak. Begitu pula dengan sejarah intelektual di Nusantara, mayoritas yang menjadi objek kajian selalu berpusat pada tiga tempat, yaitu, Sumatera, Aceh, dan Jawa. Sedangkan untuk daerah-daerah pedalaman cenderung termarginalkan. Hal yang demikian, dimungkinkan akan ada bagian-bagian sejarah yang luput dari perhatian bahkan tidak pernah diungkapkan. Persoalan semacam ini juga terjadi dalam bidang tafsir Al-Qur'an, yang selalu menempatkan tafsir Melayu-Indonesia sebagai objek pembahasan. Besarnya minat terhadap studi tafsir Melayu-Indonesia tersebut, bisa dipahami mengingat masuknya Islam ke Nusantara melalui kawasan ini. Terlebih bahasa Melayu pada saat itu menjadi lingua franca dan termasuk salah satu bahasa yang paling luas pemakaiannya. Akan tetapi, secara akademis, kajian tersebut mengesampingkan kajian tafsir di wilayah yang disebut pinggiran. Kajian di wilayah pinggiran yang selanjutnya disebut dengan tafsir lokal tersebut, dengan publikasi relatif kecil dan terbatas, luput dari perhatian. Padahal ia begitu signifikan dalam menggambarkan besarnya pengaruh jaringan Islam di Nusantara. Sejumlah tafsir di Madura misalnya, yang memberikan pengaruh pada masayarakat luput dari perhatian dan kajian secara serius.

Sebaliknya, objek kajian tentang Madura yang banyak diminati adalah bidang kesenian dan kebudayaan. Di antara contohnya adalah Helene Bouvier mengkaji jenisjenis seni yang berkembang di Madura, A. Latief Wiyata membahas tentang tradisi carok yang menjadi ciri khas Madura, begitupun dengan Mien A. Rifa'ie mengidentifikasi pribahasa-pribahasa yang dapat mempengaruhi perilaku dan pandangan orang Madura, dan sebagainya. Selain kesenian, ritual keagamaan, seperti tarekat juga menjadi objek kajian para peneliti. Salah satu contohnya, Martin van Bruinessan yang mengkaji tentang tarekat Naqsabandiyah di Madura. Jarang sekali peneliti tertarik dengan kajian disiplin keilmuan tertentu, seperti tafsir dan hadits. Walaupun ada, yang lebih banyak ditulis adalah yang berhubungan dengan ibadah amaliyah atau biasa disebut fiqih (fiqih sentris). Padahal, percakapan tentang keilmuan tafsir bukannya tidak mungkin terjadi, mengingat Madura dikenal dengan penduduknya yang religius. Persinggungannya dengan Al-Qur'an yang cukup intens, memungkinkan Al-Qur'an tidak sekedar menjadi laku ritual, tetapi bisa saja berkembang pada dimensi intelektual, yakni di bidang penafsiran. Oleh karena itu, maka tulisan tentang sejarah dan perkembangan penulisan tafsir di Madura ini penting untuk dikaji.

\section{PERSINGGUNGAN MASYARAKAT MADURA DENGAN AL-QUR'AN}

Proses masuknya Islam ke Madura tidak terlepas dari penyebaran Islam di tanah Jawa. Pada abad ke-15 Islam masuk melalui jalur perdagangan oleh sejumlah pedagang dari Gujarat, Malaka dan Sumatera yang singgah di pelabuhan pantai Madura, terutama di pelabuhan Kalianget. ${ }^{1}$ Sebelumnya, sekitar tahun 1400 -an ada ulama penyebar Islam

${ }^{1}$ Kalianget merupakan pelabuhan yang sangat penting dan banyak dikunjungioleh pedagangpedagang yang hendak ke daerah Utara seperti halnyake Sulawesi, Kalimantan dan lain sebagainya. Oleh karenanya timbul persinggahan budaya dan religi, antara penduduk asli Madura dengan para pendatang yang singgah. Lihat, Abdurachman, Sejarah Madura, (Sumenep: Offset Matahari, 1971), cet. 5 , h. 16 .

72 | Al-Fanar: Jurnal Ilmu Al-Qur'an dan Tafsir 
di daerah Madura bagian timur, Sumenep, bernama Raden Bindaran Dwiryapadha yang dikenal dengan nama Sunan Padusan. ${ }^{2}$ Lebih awal lagi, penyebaran Islam di Madura terjadi pada masa pemerintahan Panembahan Joharsari pada tahun 1330 -an. ${ }^{3}$ Hal ini menunjukkan bahwa pada abad ke-13 ketika islamisasi di Nusantara melalui beberapa kerajaan, Madura yang berafiliasi dengan kerajaan di tanah Jawa, juga menunjukkan adanya pengaruh agama Islam. ${ }^{4}$ Begitu pula dengan corak keagamaan pada saat itu berlangsung relatif sederhana. Pengajaran Islam fokus pada hal-hal dasar, misalnya pengucapan syahadat, shalat dan cara membaca Al-Qur'an. Sebagaimana dikutip dari penjelasan Iik Arifin Mansurnoor;

"When some villagers or members of Tanean Lanjang (extended compound) did eccept Islam, intensive interaction on the basic tenets of the religion was conducted. Although a general framework of Islam doctrine was introduced, this level was mainly concerned with the direct practices of Islam such as pronouncing the syahadat (unicity of God and prophethood of Muhammad), daily ritual prayers, reading the Quran and others." ${ }^{5}$

Keberadaan Al-Qur'an pada masa itu hanya sebatas "dibaca" saja, tidak pada tahap pemahaman. Persoalan utama adalah mengubah cara pandang (mindset) menyangkut keyakinan yang sebelumnya dianut, yaitu kepercayaan pribumi, sinkretisme. Secara lambat laun masyarakat diarahkan untuk membiasakan diri dengan ajaran barunya.

${ }^{2}$ Sunan Padusan adalah keturunan Arab, ayahnya bernama Usman Haji, anak dari Raja Padita, saudara dari Sunan Ampel. Pada waktu itu rakyat Sumenep sangat tertarik terhadap pendekatan dakwah yang dilakukan oleh Sunan Padusan dalam menyebarkan Agama Islam, sehingga mempengaruhi Raja yang berkuasa padawaktu itu yaitu Pangeran Jokotole (Surodiningrat III) masuk Agama Islam. Dalam dakwahnya, apabila seorang santri telah dianggap dapat melakukan rukun Islam, maka ia dimandikan dengan air yang dicampur dengan bermacam-macam bunga yang baunya harum. Semacam ini disebut "Edudus", dan tempat upacara memandikan itu disebut "Desa Padusan”, guru yang mengajar tersebut diberi nama "Sunan Padusan”. Lihat, Iskandar Zulkarnain, Sejarah Sumenep, (Sumenep: Dinas Pariwisata dan Kebudayaan Kabupaten Sumenep, 2003), h. 67.

${ }^{3}$ Iskandar Zulkarnain, Sejarah Sumenep, h. 69. Cerita panjang yang lain tentang Islam di sumenep tertulis dalam Sejarah Dalem, yang kemungkinan dikutip dari silsilah raja JawaMadura yang lebih tua. Dalam cerita tersebut muncul adipati Kanduruwan yang konon masih putera Raja Demak, yang menjadi pegawai Ratu Mas Kumambang, ratu Putri (Prabu Kenya) di Japan (Majapahit). Atas perintah tuan putrinya, adipati Kamduruwan menyerang Sumenep. Pertempuran berlangsung seru di wilayah Lenteng Sumenep. Dalam pertempuran itu adipati Sumenep yang bernama Arya Winabaya gugur di medan perang tersebut, dan setelah meniggal disebut pangeran Siding Puri. Kuburan Pangeran Siding Puri pun sudah dalam bentuk kuburan Islam. Lihat, H.J. Graaf, Puncak Kekuasaan Mataram, (Jakarta: Grafitipress 1986), h. 75.

${ }^{4}$ Dalam sejarah nasional tercatat bahwa pada tahun 1222 kerajaan Kediri berhasil di taklukkan oleh Tumapel. Semula tumapel adalah wilayah taklukan Kediri dan diperintah raja bawahan Ranggah rajasa yang terkenal dengan nama Ken Angrok. Peristiwa ini menjadikan Madura beralih penguasaan ke tangan Tumapel, yang nantinya dikenal dengan kerajaan singasari. Hal ini menunjukkan dengan berakhirnya kekuasaan kerajaan Kediri di Maura, maka menutup pula preode prasejarah Madura. Sejak pemerintahan Wangsa Rajasa yang di mulai ken angrok itu memang terdapat peninggalan berupa prasasti dan bahan-bahan tertulis yang secara tegas mengacu pada Madura. lihat, S. Kartodirdjo, M.D Poesponegoro dan N Notosusanto, Sejarah Nasional Indonesia II, (Jakarta: Balai Pustaka 1977), h. 20.

${ }^{5}$ Iik Arifin Mansurnoor, Islam in an Indonesian World, Ulama of Madura, (Yogyakarta: Gadjah Mada University Press, 1990), h. 13. 
Walaupun terkadang, kebiasaan lama seperti keahlian dalam perdukunan masih dilakukan. Akan tetapi lama-kelamaan berubah, misalnya isi (content) yang digunakan beralih pada idiom-idiom dan simbol-simbol Islam. ${ }^{6}$ Hal seperti inilah yang kemudian oleh Agus Sunyoto disebut dengan akulturasi. ${ }^{7}$

Tahap pertama penetrasi Islam, penyebaran Islam masih relatif terbatas di kota-kota pelabuhan. Akan tetapi, dalam waktu yang tidak terlalu lama, Islam mulai menempuh jalannya memasuki wilayah-wilayah pesisir lainnya dan pedesaan. Pada tahap ini, para pedagang, dan ulama-ulama yang sekaligus Wali Songo dengan murid-murid mereka memegang peranan penting dalam penyebaran tersebut. ${ }^{8}$ Sunan Giri (Raden Paku) yang merupakan salah satu dari sembilan wali dan salah satu murid dari Sunan Ampel, adalah orang yang bertugas mengislamkan wilayah seperti Madura, Lombok, Makasar, Hitu, dan Ternate.

Sunan Giri mengutus dua santrinya yang keturunan Arab yang bernama Sayyid Yusuf al-Anggawi untuk Madura bagian timur (Sumenep dan pulau-pulau di sekitarnya) dan Sayyid Abdul Mannan al-Anggawi untuk Madura bagian barat (Bangkalan, Sampang, dan Pamekasan). Makam Sayyid Yusuf al-Anggawi terletak di Desa Talango Pulau Poteran yang berhadapan dengan pelabuhan Kalianget. Sedangkan makam Sayyid Abdul Mannan al-Anggawi terletak di Desa Pangbatok Kecamatan Proppo Pamekasan, yang lebih dikenal dengan sebutan Buju' Kasambih. Putra Sayyid Abdul Mannan adalah Syeikh Basyaniah yang dijuluki Buju' Tompeng, makamnya berada di Batuampar Pamekasan. ${ }^{9}$

Pada abad ke-17 di Sumenep terdapat seorang tokoh penyebar agama Islam yang lain, ia bernama Pangeran Katandur. Keturunnya banyak yang berhasil mengislamkan penduduk Madura. Salah satu keturunnya adalah Bindara Saud yang menjadi penguasa Sumenep dari tahun 1750-1760, dan menikahi R.A Tirtonegoro, pengusa Sumenep pada masa itu. Selanjutnya pada abad ke-18 proses Islamisasi di Sumenep semakin meluas ketika diperintah oleh putra Bindara Saud yang bernama pangeran Natakusumo (Sumolo). Ia membangun keraton Sumenep dan Masjid jamik. ${ }^{10}$ Sebelumnya, Pangeran Natakusumo mengadakan musyawarah dengan para alim ulama, sesepuh,

${ }^{6}$ Iik Arifin Mansurnoor, Islam in an Indonesian World, Ulama of Madura, h. 5.

7 Terjadinya peleburan antara budaya dengan nilai-nilai keagamaan. Diterimanya Islam oleh penduduk pribumi, secara bertahap membuat Islam terintegrasi dengan tradisi, norma, dan cara hidup keseharian penduduk lokal. lihat, Agus Sunyoto, Atlas Wali Songo, h. 144. Lihat juga Iik Arifin Mansurnoor, Islam in an Indonesian World, Ulama of Madura, h. 7.

${ }^{8}$ Azyumardi Azra, Renaisans Islam Asia Tenggara, (Bandung: Remaja Rosdakarya, 1999), h. 34.

${ }^{9}$ Hingga saat ini makam Sayyid Yusuf dan pemakaman Batu ampar banyak dikunjungi peziarah dari Madura dan luar Madura. lihat, A. Sulaiman Sadik, Sangkolan: Legenda ban Sajara Madhura, (Pamekasan: Pemerintah Kabupaten Pamekasan, 2006), h. 67.

${ }^{10}$ Masjid itu pendiriannya memakai arsitek Cina bernama Lauw Piango, yaitu cucu dari Lawun Khun Thing. Kedatangan Lauw Khun Thing ke sumenep adalah akibat terjadinya huruhara Thionghoa di Semarang Tahun 1740 M. lihat, Bendara Akhamad, Lintasan Sejarah Sumenep dan Asta Tinggi beserta Tokoh didalamya, (Sumenep: Barokah, 2011), h. 44. 
dan tokoh masyarakat untuk merencanakan pendirian masjid baru tersebut. ${ }^{11}$ Dengan selesainya bangunan Keraton yang megah itu, rakyatnya membangun dimana-mana, baik diperkotaan maupun pedesaan, lebih-lebih di bidang keagamaan diantaranya: Mushalla, Langgar dan lain-lainnya. Begitu juga kegiatan-kegiatan seperti: pengajian di musholla, Masjid-Masjid dan di tempat lainnya banyak sekali. Hal ini menunjukkan bahwa pengajaran Al-Qur'an sudah ada sejak masa kerajaan, yang berpusat di Masjid dan langgar-langgar. ${ }^{12}$

Islamisasi di Madura, dibanding di Jawa, berlangsung relatif "tuntas" sedemikian tuntas Islamnya itu. Disebut tuntas karena mayoritas penduduknya beragama Islam. Jarang ditemukan wilayah di pedalaman yang tidak tersentuh oleh dakwah Islam. Semuanya mendapatkan ajaran Islam secara merata. Sehingga tidak heran apabila Islam menjadi identitas dan tradisi masyarakat Madura dalam hampir semua lapisannya. ${ }^{13}$ Sangat wajar apabila ada anggapan bahwa orang Madura sudah dianggap Islam sejak lahir. Salah satu bukti tercermin pada model bangunan rumah di Madura yang selalu menempatkan bangunan langgar di sisi barat halaman rumahnya. ${ }^{14}$ Langgar ini menjadi tempat shalat, mengaji dan belajar agama. Sejak kecil anak-anak di Madura sudah dibiasakan untuk belajar mengaji dan ilmu agama pada kiai (pengasuh langgar). ${ }^{15}$ Oleh karenanya, jarang menemukan orang Madura yang tidak bisa mengaji.

Ruang lingkup pendidikan langgar umumnya meliputi aspek-aspek Al-Qur'an, dan Fiqih, yang dalam praktiknya terwujud ke dalam materi pembelajaran Al-Qur'an, rukun Islam, zikir/do'a pendek, dan hubungan dengan sesama. Pengajian Al-Qur'an

${ }^{11}$ Masjid Laju (Bahasa Madura), artinya Masjid lama, peninggalan Raja Raden Tumenggung Anggadipa tahun (1626-1644) yang pada saat itu adalah sebagai Masjid Jamik, sudah tidak mampu lagi menampung jemaahnya, sehingga bilamana shalat jum'at, sampai meluas ke halaman luar. Dengan adanya hal yang demikian rupanya bagi Pangeran Natakusumo menjadi problema atau persoalan baru yang harus segera di tangani, karena kalau tidak akan membuat gelisah bagi rakyat khususnya dalam perkotaan. Sehingga dibangunlah Masjid baru tersebut.

${ }^{12}$ Abdurachman, Sejarah Madura, (Sumenep: Offset Matahari, 1971), h. 38.

${ }^{13}$ Dikatakan tuntas karena seluruh empat kabupaten di Madura mayoritas Islam, kecuali sebagian kecil warga non-Muslim. Proses Islamisasi dan institusionalisasi Islam dalam masyarakat Madura sendiri, yakni gerakan atau usaha menuju nilai-nilai Islam sejati, masih terus berlangsung. Sudah tentu dalam proses tersebut terjadi tarik menarik saling rebut pengaruh, bahkan kerap terjadi ketegangan, baik secara terbuka maupun diam-diam. Akan tetapi hampir seluruh fenomena sosial agama dan pola sosial-budaya di Madura berlangsung dalam ranah atau bazar kebudayaan masyarakat Muslim. Lihat Jamal D. Rahman, Islam Madura dan Kesenian: Pengalaman dan Kesan Pribadi (Sumenep: Makalah, 2007), h. 3-4. dan lihat A. Latief Wiyata, Carok: Konflik Kekerasan dan Harga diri Orang Madura, (Yogyakarta: LKis, 2012), h. 41-42.

${ }^{14}$ Bangunan langgar selalu berada di ujung halaman bagian barat sebagai simbolisasi lokasi Ka'bah yang merupakan kiblat orang Islam ketika melakukan ibadah salat. Lihat, Ali Azis, "Negeri Mullah, Negeri Beribu Kisah", dalam AULA Majalah Nahdlatul Ulama, Nomor 11 Tahun XXXI, November 2009, h. 51.

15 Pengasuh langgar, dalam bahasa Madura disebut juga kiai dengan panggilan kyaeh, atau ma'kaeh. Tapi sebutan yang kedua (ma'kaeh) sudah berkonotasi peyorative. Karena istilah yang lazim digunakan adalah kiai atau kyaeh. Tidak sebagaimana istilah Jawa, kiai dalam terminologi bahasa Madura merupakan istilah khas yang hanya diperuntukkan kepada para alim ulama. Oleh karenanya, predikat kiai senantiasa berhubungan dengan suatu gelar yang menekankan kemuliaan dan pengakuan yang diberikan secara sukarela kepada ulama dan pemimpin masyarakat setempat sebagai sebuah tanda kehormatan bagi kehidupan sosial dan bukan merupakan suatu gelar akademik. 
ditekankan pada pengenalan huruf hijâiyah hingga kemampuan membaca Al-Qur'an secara tartil. Metode yang digunakan bertahap. Pertama, belajar melafadzkan satu persatu huruf arab menurut kaidah Baghdadiyah. Kedua, mengenal lebih dekat masingmasing huruf dengan menyebut tandanya, misalnya; alif tidak bertitik, $b a$ ' bertitik di bawah, sedangkan $t a^{\prime}$ dua titik di atas, dan sebagainya. Ketiga, mengeja jenis-jenis harkat ketika dipasangkan dengan huruf tertentu. Keempat, santri dikenalkan pada tanda harkat ganda/tanwin dengan cara mengeja. Kelima, setelah semua tahap di atas dianggap lancar, maka kemudian dilatih belajar mmembaca Al-Qur'an dengan menggunakan Juz 'Amma. Pelajaran dimulai dari belajar membaca surat al-Fatihah lalu Juz 'Amma (dari surat an-Nas, al-Falaq, al-Ikhlas, dan seterusnya ke depan). Setelah Juz 'Amma selesai, baru berpindah pada kitab Al-Qur'an lengkap (30 juz). ${ }^{16}$ Setelah santri tamat (khatam) Al-Qur'an $30 \mathrm{Juz}$ dan dapat membaca dengan lancar, biasanya diadakan selamatan sebagai bentuk syukur karena sudah bisa membaca Al-Qur'an. ${ }^{17}$

Demikian pergumulan masyarakat Madura dengan Al-Qur'an pada masa-masa awal Islam diperkenalkan. Hingga pada tingkat selanjutnya, yaitu mengaji kitab tafsir di pesantren-pesantren. Pesantren sendiri bagi masyarakat Madura merupakan salah satu bukti keberagamaan yang sangat kental. Bahkan pesantren adalah lembaga pendidikan tertua yang masih eksis di Madura hingga sekarang. Beberapa pesantren bahkan didirikan pada abad ke-17 dan ke-18. ${ }^{18}$ Di pesantren tersebut, para santri belajar ilmu agama, termasuk di dalamnya adalah tafsir.

Secara umum, Kitab tafsir yang digunakan adalah Tafsir Jalalain, walaupun tafsir karya Baidhawi juga dikenal namanya tapi sangat jarang kiai yang mengajarkannya. ${ }^{19}$ Hal ini senada dengan apa yang disampaikan oleh Kiai Abd. Basith AS, salah satu pengasuh di Pondok Pesantren Annuqayah, Guluk-guluk, Sumenep Madura, mengatakan bahwa yang menjadi rujukan utama di bidang Tafsir adalah Tafsir Jalalain, selain itu beliau juga menyebutkan Tafsir Ibnu Katsir dan Tafsir Shawi. Hal ini menunjukkan bahwa tafsir pada abad ke-19 masih belum dianggap sebagai bagian yang sangat penting dalam kurikulum pesantren. Sebaliknya, fiqih mendapat porsi lebih banyak dan mendapat perhatian yang lebih besar. ${ }^{20}$ Di antara semua cabang ilmu agama Islam,

${ }^{16}$ Kebiasaan orang Madura mengenalnya Qur'an Kene', qur'an yang hanya memuat satu juz saja. sedangkan selanjutnya disebut Qur'an Rajeh, yang berisi juz awal hingga akhir. Selengkapnya lihat, Moh. Wardi, "Pilihan Belajar Al-Qur'an di Madura: Konversi dari Langgar ke Taman Pendidikan al-Quran" Jurnal Kabilah, Vol. 1 No. 1 Juni 2016. Lihat juga, Kuntowijoyo, Perubahan Sosial dalam Masyarakat Agraris: Madura 1850-1940, (Yogyakarta: Matabangsa, 2002), h. 331. Juga bisa dilihat dalam Hubb de Jonge, Madura dalam Empat Zaman: Pedagang, Perkembangan Ekonomi, dan Islam, (Jakarta: Gramedia, 1989), h. 251, 270.

${ }^{17}$ Mohammad Kosim, "Langgar sebagai Institusi Pendidikan Keagamaan Islam", Tadris Jurnal Pendidikan Islam, Volume 4. Nomor 2. 2009, h. 245.

18 Seperti Pondok Pesantren Kembang Kuning (1619), Pondok Pesantren Nazhatul Thullab Prajjan, Sampang (1702), Pondok Pesantren Panggung, Sumenep (1757), Pondok Pesantren Banyuanyar Pamekasan (1785), Pondok Pesantren Ketengan, Sebeneh, Karomah, Demangan, Burneh, dan sebagainya. Keterangan lebih jelas lihat, Muhammad Tidjani Jauhari (ed. Hamzah Arsa), Membangun Madura, (Jakarta: Taj Publishing, 2008), h. 16.

${ }^{19}$ Martin Van Bruinessan, Kitab Kuning, Pesantren dan Tarekat, h. 179.

${ }^{20}$ Martin Van Bruinessan, Kitab Kuning, Pesantren dan Tarekat, h. 121. Selain itu yang menjadi alasannya karena Fiqih diamalkan pertama kali untuk kebutuhan primer dalam beribadah, wawancara dengan KH. Abd. Basith AS pada hari Jumat, 28 Juli 2017. 
fiqih dianggap paling penting karena fiqih mengandung berbagai implikasi konkrit bagi pelaku keseharian individu maupun masyarakat. Fiqih yang menjelasakan kepada kita hal-hal yang dilarang dan tindakan-tindakan yang dianjurkan. Sehingga tidak heran apabila fiqih menjadi primadona di antara semua mata pelajaran di Pesantren.

Sama halnya dengan perkembangan tafsir di Indonesia secara umum, tidak lahirnya mufasir dalam arti yang sesungguhnya karena mereka hanya diperkenalkan dengan satu kitab tafsir saja, yaitu Tafsir Jalalain, sementara tafsir Tarjuman al-Mustafid tidak populer di Pesantren. Bahkan di Madura pun sampai pada abad ke-19 belum ada tandatanda penulisan tafsir. Dalam hal ini Steenbrink mengungkapkan;

"Walaupun Al-Qur'an dan Hadits merupakan sumber utama agama Islam, namun studi khusus yang berfokus pada kitab suci ini atau kumpulan hadits belum dilakukan. Dan ternyata hanya satu buku tafsir saja yang dipakai. Hal ini membuktikan bahwa pendekatan terhadap Al-Qur'an dan hadits tidak secara langsung, tetapi melalui seleksi yang sudah diadakan oleh kitab-kitab lain, khususnya fiqih", ${ }^{21}$

Kondisi masyarakat Madura secara umum dalam menghadapi berbagai persoalan yang terjadi membutuhkan penanganan yang cepat. Sedangkan memecahkan masalah dengan masih melalui tafsir yang jelas memakan waktu dan proses yang panjang dan lama. Hal tersebut sangat tidak mungkin. Apalagi tafsir Al-Qur'an tidak menjelaskan permasalahan-permasalahan itu secara rinci dan praktis, tetapi bersifat umum dan masih teoritis. Sebaliknya, kitab-kitab fiqih, tasawuf, atau tauhid langsung membahas permasalahan tersebut secara rinci praktis, dan langsung dapat diterapkan dalam kehidupan sehari-hari (applicable).

Di samping itu, selain karena kondisi masyarakatnya, fenomena minimnya tafsir di Madura dipengaruhi oleh ketidak tertarikan kiai Madura terhadap penulisan tafsir, terlebih kiai di pondok salaf. Seperti yang diungkapkan oleh bapak Fathurrosyid ${ }^{22}$ sedikitnya karya tafsir di Madura karena mereka bersifat reserve terhadap hadis " Man qaala fi Al-Qur'an bi ra'yihi fal yatabawwa' maq'adahu min al-nar". ${ }^{23}$ Hadis ini menurutnya seringkali dijadikan justifikasi kiai tidak produktif menulis tafsir. ${ }^{24}$ Pernyataan tersebut sama dengan yang pernah diungkapkan oleh Syeikh Nawawi al-Bantany dalam sebuah pengantarnya di Kitab Tafsir Marah Labid. ${ }^{25}$ Bahkan, hal

${ }^{21}$ Karel A. Steenbrink, Beberapa Aspek tentang Islam di Indonesia abad ke-19, (Jakarta: Bulan Bintang, cet ke-1, 1984), h. 157.

${ }^{22}$ Salah satu dosen di Jurusan ilmu tafsir dan Al-Qur'an di INSTIKA Guluk-guluk Sumenep, tentang beliau akan dibahas dalam beberapa karya tafsir di Madura. sebab beliau juga menulis tentang Semiotika Kisah Al-Qur'an.

${ }^{23}$ Lihat, Abu Isa Muhammad bin Isa al-Turmudzi al-Silmi, Sunan al-Turmudzi, (Beirut: Dar ihya' alTuras al-Arabi, tt), Juz 5, h. 199. Bunyi lengkapnya;

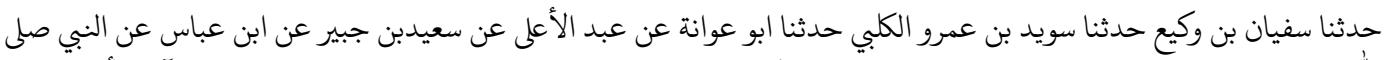

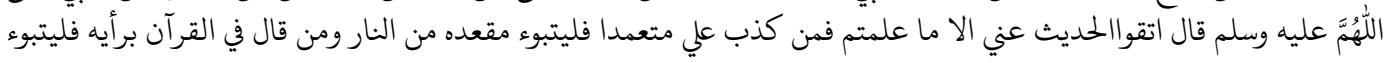

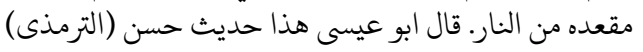
keberanian untuk menulis tafsir ini sekalipun dorongan yang bertubi-tubi datang dari berbagai pihak. Ia khawatir terjerumus pada ancaman Nabi yang mengatakan "barang siapa berbicara tentang AlQur'an dengan ra'yunya, maka silahkan mengambil tempat di neraka”. Setelah berhasil membangun keberanian, Nawawi akhirnya memutuskan untuk menulis tafsir ini. Ia menyebutnya sebagai upaya meneladani para ulama' salaf yang senantiasa menulis dan membukukan pemikiran-pemikirannya. Lihat Nawawi al-Bantani, Marah Labid, h. 2. 
tersebut oleh sebagian ulama di Madura justru dijadikan logika terbalik untuk tidak menafsirkan sama sekali.

Agaknya, beberapa poin tersebut cukup menggambarkan kepada kita mengapa tafsir kurang mendapat tempat dalam kurikulum pengajaran tafsir di Madura sejak dulu. Jadi, berdasarkan kenyataan ini, bukanlah suatu yang aneh jika tafsir al-Quran kurang berkembang di Madura sejak awal permulaan Islam masuk sampai akhir abad ke-19 atau memasuki awal abad ke-20. Baru kemudian setelah memasuki paruh kedua abad ke-20 tampak beberapa karya tafsir walaupun perkembangannya juga tidak cukup signifikan.

\section{SEJARAH AWAL PENULISAN TAFSIR DI MADURA}

Seperti yang diungkapkan Azyumardi Azra bahwa jaringan kaum muslimin sebenarnya terbentuk melalui perjalanan (rihlah), baik untuk kepentingan naik haji (rihlah mubarokah) ke Mekkah dan Madinah, maupun perjalanan pengembaraan seperti yang dilakukan Ibn Bathuthah dan perjalanan menuntut imu (Rihlah 'ilmiyah) ${ }^{26}$ Fenomena inilah yang sebenarnya membentuk jaringan keulamaan antara ulama di Madura dengan Ulama Timur Tengah. Perjalanan ke Mekah untuk Ibadah haji tidak hanya dimaksudkan sebagai laku ritual tetapi juga sebagai laku intelektual. Ulama yang berkiprah mentransmisikan keilmuan dari Mekah dan membangun kearifan lokal dalam tradisi di tanah air tersebut adalah Syaikhona Khalil, ${ }^{27}$ guru dari seluruh ulama Jawa pada masanya. ${ }^{28}$

Selama di Mekah, Syaikhona Khalil belajar kepada sejumlah Ulama yang berkompeten di bidangnya. Diantara gurunya tersebut adalah Syeikh Nawawi al-Bantani (mufassir), Syeikh Umar Khatib Bima (ahli fiqh), Syeikh ahmad Khatib Sambas (ahli tarekat). Selain itu Syaikhona Khalil juga berguru kepada Syeikh Ali Rahbini yang memiliki sanad Qira'ah Sab'ah. Ia juga belajar kepada Syeikh Usman bin Hasan adDimyati, Sayyid Ahmad bin Zaini Dahlan, Syeikh Musthafa bin Muhammad al-Afifi al-Makki, Syeikh Umar As-Sami, Syekh Aththar, dan Syeik Abun Naja, dan masih banyak lagi. ${ }^{29}$ Tak heran apabila ia ahli di bidang fiqih dan tarekat, serta menguasai

${ }^{26}$ Azyumardi Azra, Jaringan Ulama Timur Tengah dan Kepulauan Nusantara abad XVII \& XVIII, h. XI.

${ }^{27}$ Syaikhona Kholil lahir pada hari Selasa tanggal 11 Jumadil Akhir $1235 \mathrm{H}$ atau 27 Januari $1820 \mathrm{M}$, dan meninggal dunia pada usia 90 Tahun tanggal 29 Ramadhan $1343 \mathrm{H}$ atau 24 april 1925 M. Silsilah nasab Muhammad Kholil memang sudah ditakdirkan berasal keluarga ulama. Bisa dilihat dari Ayahnya, KH. Abdul Lathif, mempunyai pertalian darah dengan Sunan Gunung Jati. Ayah Abdul Lathif adalah Kyai Hamim, anak dari Kyai Abdul Karim. Yang disebut terakhir ini adalah anak dari Kyai Muharram bin Kyai Asror Karomah bin Kyai Abdullah bin Sayyid Sulaiman. Sayyid Sulaiman adalah cucu Sunan Gunung Jati. Lihat, Ibnu Assayuthi Arrifai, Korelasi Syaikhona Kholil Bangkalan dan NU (Cirebon: Al Haula Press. 2010), h. 46.

${ }^{28}$ Syaikhona Khalil menjadi episentrum (kiblat) bagi para ulama dan pengasuh Pesantren dalam pengembangan dan penyiaran agama Islam. Sebagaimana yang diungkapkan oleh Gus Dur, bahwa Syaikhona Khalil merupakan ulama besar yang menjadi guru dari hampir semua kiai terpandang di seluruh Jawa pada waktu itu. Sebab Gus Dur memandang bahwa sosok Syaikhona Khalil mampu menggabungkan kedua kecenderungan fiqih dan tarekat dengan tanpa mempertentangkan keduanya. Lihat, Fuad Amin Imron (ed. Nico Ainul Yakin), Syaikhona Khalil Bangkalan Penentu berdirinya Nahdlatul Ulama, (Surabaya: Kalista, 2016), h. 175.

${ }^{29}$ Zainul Milal Bizawie, Masterpiece Islam Nusantara, Sanad dan Jejaring Ulama-Santri, h. 436 dan Fuad Amin Imron (ed. Nico Ainul Yakin), Syaikhona Khalil Bangkalan Penentu berdirinya Nahdlatul Ulama, h. 68. 
bidang tata bahasa Arab (Nahwu). Di dalam berbagai kesempatan selalu menggunakan bait-bait alfiyah untuk menyikapi atau menjawab berbagai persoalan. Semasa mudanya pun, Syaikhona Khalil sudah berhasil menghafal Al-Qur'an.

Tidak seperti Syeikh Nawawi al-Bantani, ia memutuskan untuk kembali ke Bangkalan. Seperti Kiai Shaleh Darat, ia menjadi penghubung antara horizon Mekah dan Nusantara dengan mendirikan pesantren dan masjid-masjid. Mendirikan pesantren dipandang paling efektif dalam kegiatan syiar Islam dan membela hak-hak dasar bagi masyarakat di bidang pendidikan. Pesantren yang didirikan ada dua, yaitu, Pesantren Jangkebuan dan Kademangan. ${ }^{30}$ Sedangkan masjid yang dibangun ada sekiar delapan masjid, diantaranya adalah Masjid Jami' Kamal, Masjid Jami' Socah, Masjid Jami' Kwanyar, dan lain sebagainya. ${ }^{31}$ Masjid tersebut dimaksudkan tidak hanya sebagai sarana peribadatan, tetapi juga sebagai media dakwah kepada masyarakat. Hal ini menunjukkan bahwa masjid pada waktu itu menjadi sentral keilmuan di samping Pesantren.

Di samping itu, Syaikhona Khalil juga mendakwahkan Islam lewat jalur kekuasaan. Ia diminta oleh Kanjeng Adipati Bangkalan untuk menjadi penasehat kadipaten dan sekaligus mengajar agama bagi seluruh keluarga Adipati. ${ }^{32}$ Ketokohan dan kealiman Syaikhona Khalil ternyata membuat Kanjeng Adipati berkeinginan untuk menjadikannya mantu, yaitu dengan salah satu kerabat kadipaten yang bernama Raden Ayu Assek putri dari Pangeran Lodrapati. Akhirnya mereka menikah pada tanggal 30 Rajab 1278 Hijriyah. Pernikahan tersebut merupakan simbol kekuatan dua poros, yaitu poros ulama dan priyayi/bangsawan. Menyatunya dua simbol tersebut semakin memperkuat posisi Syaikhona Khalil di mata masyarakat dalam dakwah Islam kala itu. Hal itu menjadi momentum yang tepat, mengingat masyarakat Madura masih melihat kekuasaan sebagai simbol pengaruh yang sukup kuat di tengah-tengah masyarakat. ${ }^{33}$

Selain pesantren dan masjid, ada karya yang ditinggalkannya. Berupa kitab dan karya tulis. Kitab-kitab tersebut adalah; kitab as-Silah fi bayanin-nikah, sebuah kitab tentang pernikahan yang meliputi hukum dan adab. Rangkaian shalawat yang dihimpun oleh KH. Muhammad Khalid dalam kitab I'anatur Raqibin. Dzikir dan wirid yang dihimpun oleh KH. Musthafa Bisri dalam kitab yang berjudul al-Haqibah. Semua kitab tersebut

\footnotetext{
${ }^{30}$ Setelah putrinya, Siti Khatimah dinikahkan dengan keponakannya sendiri, yaitu Kyai Muntaha; pesantren di Desa Cengkubuan itu kemudian diserahkan kepada menantunya. Kiai Kholil sendiri mendirikan pesantren lagi di daerah Kademangan, hampir di pusat kota; sekitar 200 meter sebelah Barat alun-alun kota Kabupaten Bangkalan. Letak Pesantren yang baru itu, hanya selang 1 Kilometer dari Pesantren lama dan desa kelahirannya. Di tempat yang baru ini, Mbah Kholil juga cepat memperoleh santri lagi, bukan saja dari daerah sekitar, tetapi juga dari Tanah Seberang Pulau Jawa. Lihat, Fuad Amin Imron (ed. Nico Ainul Yakin), Syaikhona Khalil Bangkalan Penentu berdirinya Nahdlatul Ulama, h. 73.

${ }^{31}$ Fuad Amin Imron (ed. Nico Ainul Yakin), Syaikhona Khalil Bangkalan Penentu berdirinya Nahdlatul Ulama, h. 74.

${ }^{32}$ Kanjeng Adipati yang berkuasa waktu itu merupakan keturunan Syarifah Ambami Ratu Ibu yang bersambung nasab kepada Sunan Giri. Lihat, Fuad Amin Imron (ed. Nico Ainul Yakin), Syaikhona Khalil Bangkalan Penentu berdirinya Nahdlatul Ulama, h. 71.

${ }^{33}$ Fuad Amin Imron (ed. Nico Ainul Yakin), Syaikhona Khalil Bangkalan Penentu berdirinya Nahdlatul Ulama, h. 73.
} 
telah dicetak dan disebarluaskan. ${ }^{34}$ Selain itu masih ada karya Syaikhona Khalil dalam bentuk manuskrip. Diantaranya adalah kitab Tarjamah alfyah, kitab asmaul husna yang berbentuk nadzam, dan ijazah berupa doa dan amalan-amalan atau hizib yang tersebar di sejumlah kiai. ${ }^{35}$ Masih ada lagi karya Kiai Syaikhona Khalil berupa tulisan tangan beberapa ayat suci Al-Qur'an dan hadad. Karya tulis tersebut terletak di museum. ${ }^{36}$

Melihat karya-karya yang ditinggalkan dan latar keilmuan yang mumpuni dalam segala bidang keilmuan termasuk tafsir dan tata bahasa, tak heran apabila Syaikhona Khalil juga melakukan proses penerjemahan Al-Qur'an. ${ }^{37}$ Dari sinilah dapat diketahui geliat penulisan tafsir pertama di Madura, yaitu dengan ditemukannya manuskrip mushaf yang ditulis oleh Syekh Abdul Karim, kakek buyut Syaikhona Khalil, sementara tulisan antar baris adalah tulisan Syaikhona Khalil yang merupakan terjemah ma'ani dan penjelasan atas masing-masing kata dalam Al-Qur'an dengan menggunakan bahasa Madura pegon. Melihat dari uraiannya, sangat kental dengan qawaid bahasa Arab atau I'rab, karena Syaikhona memang ahli di bidang gramatika bahasa arab (Nahwu). Dalam kolofon naskah tersebut, dijelaskan bahwa teks tersebut selesai ditulis pada tahun 1320 $\mathrm{H}(1900 \mathrm{M}){ }^{38}$

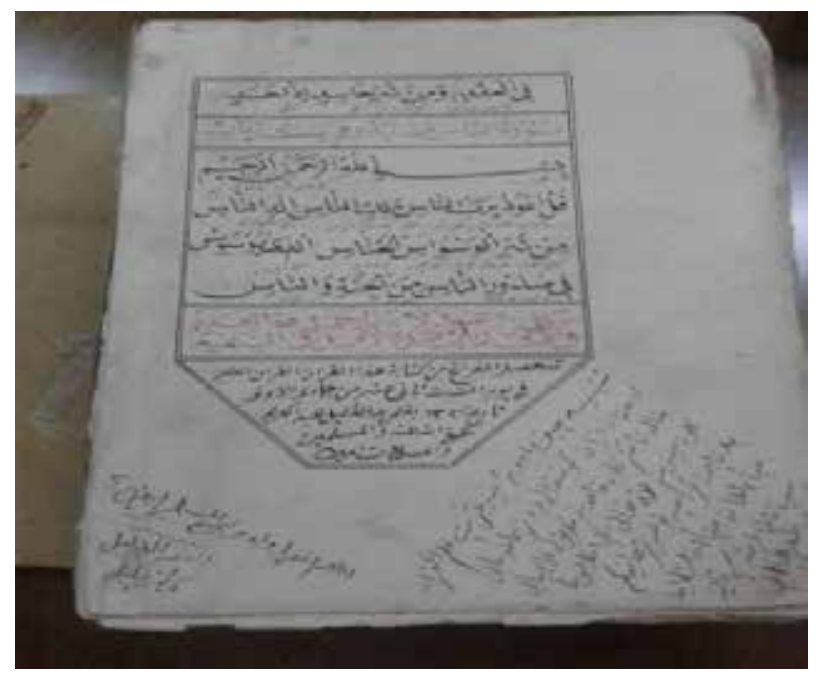

Gambar 1: Naskah al-Quran terjemah bahasa Madura Kiai Khalil Bangkalan

Dalam gambar tersebut tampak keterangan tambahan yang ditulis oleh Syaikhona

${ }^{34}$ Ali bin Badri Azmatkan, Dari Kanjeng Sunan Sampai Romo Kiai Syaikhona Muhammad Khalil Bangkalan, telaah sejarah \& riwayat hidup, (Bangkalan, Ikazi, 2007), h. 88.

${ }^{35}$ Saifur Rahman, Biografi dan Karomah Kiai Khalil Bangkalan, Surat kepada anjing hitam, (Jakarta: Pustaka Ciganjur, 2001), h. 67.

36 Oleh pengelola museum Tjakradinimgrat Bangkalan, disajikan dalam dua bentuk, yakni berupa naskah turunan yang sudah tersaji dalam bentuk foto copy. Lihat, Fuad Amin Imron (ed. Nico Ainul Yakin), Syaikhona Khalil Bangkalan Penentu berdirinya Nahdlatul Ulama, h. 48.

${ }^{37}$ Pada saat di Mekah untuk mencukupi kebutuhan sehari-hari, Syaikh Kholil bekerja mengambil upah sebagai penyalin kitab-kitab yang diperlukan oleh para pelajar. Jadi, proses terjemah sudah biasa dilakukan sebelumnya. Lihat, Zainul Milal Bizawie, Masterpiece Islam Nusantara, Sanad dan Jejaring Ulama-Santri, h. 436.

38 Informasi ini pertama kali didapat dari akun Facebook Ahmad Baso yang diposting pada tanggal 26 juli 2017. Selanjutnya melakukan klarifikasi lanjutan dengan Ahmad Baso tentang naskah tersebut secara mendalam. 
Khalil di pojok kanan bawah. Tulisan tersebut adalah peringatan tentang keutamaan membaca Al-Qur'an yang disertai dengan pemahaman maknanya. Ditulis menggunakan bahasa Madura pegon, berikut isinya;

Tanbihun: sera-sera oreng se ngarte elmu Al-Qur'an ban ma'nanah Quran tor ningaleh da' terjemanah hale sala ta' bender kalaban qo'idanah, maka olle pabecceagi kalaban se bender lillahi ta'ala hale ikhlash (...), karena se noles/ nerjema neka banya' loppana banya' ikhtilat.

Kira-kira jika dialihbahasakan ke dalam bahasa Indonesia adalah sebagai berikut, "peringatan: bagi orang yang paham ilmu Al-Qur'an dan makna Al-Qur'an, lalu mendapatkan ada terjemahan yang salah atau keluar dari kaidah Al-Qur'an, dipersilahkan untuk membenarkannya ikhlash karena Allah. Sebab, penulis buku ini banyak lupa dan kelirunya." 39

Pernyataan yang ditulis Syaikhona Khalil tersebut menunjukkan kerendah dirian (tawadhu') seorang yang berikhtiar dalam mencari keberkahan ilmu-Nya. Hal ini lumrah dilakukan oleh ulama-ulama terdahulu sebagai bentuk pengakuan, bahwa apa yang dilakukan tidak lebih dari pertolongan Allah dan selalu merasa hina di hadapan Allah. Tidak merasa sombong atas apa yang dilakukan, sebaliknya menyadari kekurangan dirinya sebagai manusia biasa yang tidak pernah luput dari salah dan dosa.

Selanjutnya, jika dilihat dari segi metodologinya, terjemah Al-Qur'an ini bisa dikategorikan ke dalam tafsir bi al-ra'yi dengan metode Ijmali dan coraknya yang lughawi. Salah satu contohnya ketika menerjemahkan lafadz maliki an-nass, dalam bahasa Indonesia berarti raja manusia, maka pada terjemah bahasa Madura, ia bermakna, se ngator manussa (yang mengatur manusia). Terjemah ini merupakan terjemah harfiyah gandul tanpa penjelasan. Artinya, teks Arab asli dialih bahsakan ke dalam bahasa lokal (Madura) tanpa ada penjelasan lanjutan. Semua terjemahan dalam mushaf tersebut, mayoritas menggunakan corak yang sama, yaitu lughawi.

\section{PERKEMBANGAN PENULISAN TAFSIR DI MADURA}

Pasca terjemah Al-Qur'an yang ditulis Syaikhona Khalil, lebih dari setengah abad lamanya tidak muncul lagi karya tafsir di Madura. persoalan seperti ini semakin menunjukkan bahwa dari sudut Islamic studies, Madura lebih dilirik oleh percakapan fiqih dari pada tafsir Al-Qur'an. Baru kemudian sekitar tahun 1960-an muncul tafsir versi terjemah bahasa Madura dan tradisi tafsir lisan (the oral interpretation) yang marak dilakukan oleh ulama di Madura. Beberapa di antaranya sebagai berikut:

\section{Terjemah Bahasa Madura}

Terjemah Tafsir Al-Qur'an al-Karim Nurul Huda karya K. Mudhar Tamim ${ }^{40}$ merupakan tafsir yang berbahasa Madura. Ditulis menggunakan bahasa latin yang

\footnotetext{
${ }^{39}$ Teks selanjutnya tidak bisa dibaca karena kualitas kertasnya yang kurang memadai.

${ }^{40}$ Memiliki Nama lengkap R. Ach. Mudhar Tamim bin KHR. Moh Tamim. Ia lahir pada tanggal 7 November tahun 1916 di Desa Barurambat Kota, sebuah desa yang beralamatkan Jl. Masegit (sebelah selatan Masjid Jami' asy-Syuhada'), Kecamatan Pamekasan, Kabupaten Pamekasan. Mudhar Tamim terlahir dari keluarga bangsawan, pasanga KHR. Moh Tamim dengan R. Ayu Tayyibah. Mbah buyutnya, KHR Ismail adalah ketua penghulu dan salah satu pendiri NU di Pamekasan yang menikahi R. Ayu Rembang, puteri R. Demang Wironegoro.
} 
masih menggunakan mesin ketik, dan untuk penulisan ayat Al-Qur'an menggunakan tulisan tangan. Penulisan tafsir ini dimulai pada hari Rabu, 16 Juli $1969 \mathrm{M}$ atau 1 Jumad al-Awwal 1389 H sampai pada hari Senin 6 Oktober 1969 atau 24 Rajab 1389. Selama kurang lebih tiga bulan, ia berhasil merampungkan penafsiran surah al-Fatihah dan surah al-Baqarah yang kemudian dicetak dalam jilid satu. ${ }^{41}$

Latar belakang penulisan tafsir ini dijelaskan oleh Mudhar Tamim secara eksplisit dalam kata pengantar bahwa salah satu tujuannya adalah dalam rangka mengawal program REPELITA (Rencana Pembangunan Lima Tahun) yang dicanangkan oleh pemerintah Orde Baru. Karya tafsir ini diproyeksikan akan dibaca setiap hari Jumat di Radio Hansip Corporation (RHANSISCO) Pamekasan sebagai media dakwah kepada seluruh masyarakat Pamekasan khususnya, dan masyarakat Madura pada umumnya. Selain itu, motivasi lain yang dijadikan landasan penulisan tafsir ini adalah upaya Mudhar Tamim dalam rangka memperluas dan mengokohkan keyakinan terhadap ajaran Islam. Hal ini dimaksudkan untuk pengabdiannya terhadap Al-Qur'an. Di samping itu, tafsir yang menggunakan bahasa Madura belum pernah ada, sehingga berkat saran dari kerabat-kerabatnya, Mudhar Tamim menyusun tafsir ini untuk memudahkan masyarakat umum yang baru bisa membaca tulisan latin dan sekedar bisa membaca Al-Qur'an. ${ }^{42}$

Sistematika penyajian dalam tafsir Nurul Huda terdiri dari tiga bagian. Pertama, penyajian ayat-ayat Al-Qur'an dalam bahasa Arab. Kedua, ayat-ayat Al-Qur'an diterjemahkan ke dalam bahasa Madura latin yang ditulis di bawah teks Arab. Ketiga, dilanjutkan dengan penjelasan makna ayat Al-Qur'an dalam bahasa Madura yang ditulis tepat di bawah teks terjemah Al-Qur'an.

Refrensi yang digunakan oleh Mudhar Tamim dalam tafsir ini cukup beragam. Mudhar Tamim banyak mengutip penjelasan-penjelasan dari tafsir klasik maupun kontemporer, seperti tafsir Yunus karya Mahmud Yunus, tafsir Fath al-Qadir karya al-Shaukani, tafsir al-Khazin karya Alaluddin Ali bin Muhammad, tafsir Ma'alim al-Tanzil karya al-Baghawi, tafsir Mahasin al-Ta'wil karya Jamaluddin al-Qasimi, tafsir al-Manar karya Muhammad Abduh dan tafsir al-Jawahir karya Tantawi Jauhari. Selain kitab tafsir, Mudhar Tamim juga merujuk pada kitab-kitab hadis, seperti kitab Sahih Bukhari, Irshad al-'Ibad, Nail al-Autar, Subul al-Salam, dan juga merujuk pada literatur Filsafat Islam hingga Bible. ${ }^{43}$

Melihat dari daftar kitab yang dijadikan rujukan, tafsir ini tergolong pada tafsir $b i$ al-ro 'yi. Porsi akal dalam penafsirannya juga cenderung dominan dari pada penggunaan riwayat. Sebab penggunaan riwayat hanya sekedar dijadikan sebagai legitimasi dari penafsirannya. Adapaun metode yang digunakan adalah tahlili (analitis). Sedangkan corak yang digunakan cenderung pada 'Adabi Ijtima' $i$ (sosial kemasyarakatan) dan fiqih. Misalnya dalam corak fiqih dapat dijumpai dalam penafsiran QS. Al-Baqarah: 173

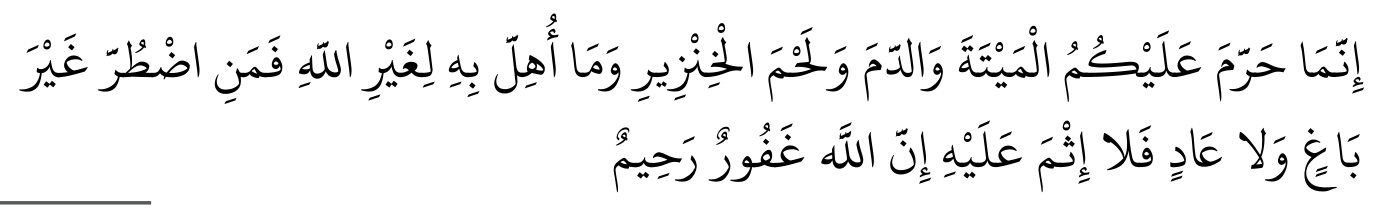

\footnotetext{
${ }^{41}$ Mudhar Tamim, Tafsir Al-Qur'an al-Karim Nurul Huda (Surabaya: tp, 1969), h. viii.

${ }^{42}$ Mudhar Tamim, Tafsir Al-Qur'an al-Karim Nurul Huda, h. viii.

${ }^{43}$ Lebih lengkap lihat daftar rujukan dalam Mudhar Tamim, Tafsir Al-Qur'an al-Karim Nurul Huda, h. ix.
} 
"Sesungguhnya Allah hanya mengharamkan bagimu bangkai, darah, daging babi dan binatang yang (ketika disembelih) disebut (nama) selain Allah. Tetapi barang siapa dalam keadaan terpaksa (memakannya) sedang ia tidak menginginkannya dan tidak (pula) melampaui batas, maka tidak ada dosa baginya. Sesungguhnya Allah Maha Pengampun lagi Maha Penyayang". (QS. Al-Baqarah [2]: 173)

Hokomma babatang, saadadjana ulama pada tjojok, hokomma babatang paneka nadjis ban haram etedda (makan); salaenna baling ban djuko' tase'.

Dabuna Rasul: “aeng tase' sottje ban halal babatangnga (djuko' se mate). Dineng baling, metorot keterangan dari Ibnu Aufaakaula aperrang ngereng Rasul. 7 kale otaba 6 kale nedda baling". Riwayat Buchari/Muslim.

Metorot Imam Malik ban Imam Sjafi'i: djuko' mate se ngambang, olle, tada' alangan. Metorot Imam Abu Hanifah, Hasan, Ibnu Saleh, Ibnu Djani, hokomma makro. Metorot Ali bin Abi Thalib r.a. kengeng. Manabi baling metorot Imam Sjafi'i/Abu Hanifah, mate otaba odi' halal, metorot faham malik, kalamon mate, hokomma haram. Kalamon odi' ebelli gellu epotong serana.

Hokomma dara: sadadjana Ulama pamanggina tjojok. Hokomma dara nadjis, haram etedda, tada' gunana (manfa'atdda). Metorot Imam Abu Hanifah, darana djuko' tase' ta' haram, sabab kalamon kerreng, pote.

Kol-tongkolan sareng ate ta' tamaso' ka hokom dara, daddi hokom aingnga sareng bagian2 laenna, hokomma haram, karana sadadjana se aguna paneka agantong ka daging sareng nadjis.

Metorot Imam Malik sotjje kalamon odi', pada kalaban binatang laenna. Metorot Imam Sjafi'I, 2 matjem. Kalamo edjilad tjeleng/babi gi' anjar, pade sareng burus (pate') e sotjje'e 7 kale (kaul djadid ketab anggidanna Imam Sjafi'i e Mesir)

Metorot kaul qadim (anggidanna Imam Sjafi'i e Bagdad): tjokop e sotjje'e sakalian. Hokom edjilat burus (pate'): esotjje'e 7 kale paneka ta' bisa epekker kalaban akal: sabab paneka pakon sjara' ${ }^{44}$

Dari kutipan penafsiran di atas, tampak bahwa ketika dihadapkan kepada persoalan fiqh, Mudhar Tamim tidak terjebak pada fanatisme madzhab. Mudhar Tamim juga tidak menyertakan komentar tentang keberpihakannya pada satu madzhab tertentu, ia hanya memaparkan dari perspektif para Imam madzhab dan membiarkannya begitu saja.

${ }^{44}$ Artinya: "hukum mengenai bangkai, seluruh ulama sepakat mengatakan najis dan haram untuk dimakan, kecuali bangkainya belalang dan ikan. Sebagaimana sabda Rasululah: Air laut suci dan halal bangkainya. Sedangkan belalang, menurut keterangan Ibnu Aufaakaula selama berperang bersama Rasul, beliau makan belalang 7/6 kali, Riwayat Bukhari dan Muslim. Menurut Imam Malik dan Imam Syafi'i: ikan yang mati dan mengapung di air boleh dimakan. Sedangkan menurut Imam Abu Hanifah, Hsan, Ibnu Saleh, Ibnu Djani, dihukumi makruh. Belalang baik mati ataupun hidup halal dimakan menurut Imam Syafi'I atau Abu Hanifah. Sedangkan menurut imam malik jika mati haram dimakan dan jikalau hidup harus dipotong kepalanya. Hukum mengenai darah, seluruh ulama sepakat mengatakan najis dan haram dimakan karena tidak ada manfaatnya. Menurut Imam Abu Hanifah, darahnya ikan laut tidak haram karena ketika mongering ia memutih. Hati dan tidak termasuk pada bagian darah yang diharamkan. Menurut Imam Malik dihukumi suci jikalau hidup, sama dengan hewan lainnya. Sedangkan menurut Imam Syafi'I ada dua macam, jika dijilat babi ataupun anjing harus disucikan tujuh kali sucian (qaul jadid) sedangkan menurut qaul qadim, hanya cukup disucikan satu kali sucian. Sebab, disucikan sebanyak tujuh kali tersebut tidak bisa dilogikakan karena sudah ketentuan syara'." Mudhar Tamim, Tafsir Al-Qur'an al-Karim Nurul Huda, h. 72-73. 
Mudhar Tamim termasuk orang yang berhati-hati dalam menafsirkan Al-Qur'an. Ia memperhatikan beberapa hal untuk dijadikan pedoman dalam penafsirannya. Diantaranya adalah sebagai berikut:

1. Memperhatikan riwayat yang berhubungan dengan makna kalimat dan asbabun nuzul.

2. Memperhatikan kisah umat terdahulu dan tokoh yang disebutkan dalam Al-Qur'an, kemudian berusaha mengambil hikmah dari cerita tersebut.

3. Memperhatikan munasabah ayat, baik dengan ayat sebelumnya atau sesudahnya

4. Memperhatikan bahasa dan perbedaan qiraat. Akan tetapi penjelasannya tidak mendapat cukup porsi. Hal ini dimaksudkan untuk menghilangkan kejenuhan bagi pembaca, mengingat yang menjadi penekanan dalam tafsir ini adalah pemahaman terhadap isi tafsir. Terlebih lagi yang menjadi sasaran tafsir Nurul Huda adalah Masyarakat yang baru bisa membaca Al-Qur'an dan sekedar bisa membaca huruf latin. ${ }^{45}$

Gaya bahasa penulisan yang digunakan dalam tafsir Nurul Huda tergolong ke dalam gaya reportase, yaitu gaya penulisan tafsir dengan menggunakan kalimat yang sederhana, elegan, komunikatif dan lebih menekankan pada hal-hal yang bersifat pelaporan serta bersifat human interest. Dari hasil reportase tersebut, di beberapa bagian disertakan kata simpul sebagai pengungkapan pesan moral Al-Qur'an. ${ }^{46}$

\section{Penafsiran Lisan (the oral interpretation)}

Pengajian tafsir di kampung-kampung sudah berlangsung lama di Madura. Mulai dari surah-surah tertentu seperti yasin, munjiyat, dan lengkap 30 Juz hingga pada Jam'iyah Sulukiyah. Salah satu contoh seperti Jam'iyah Sulukiyah yang berada di Parenduan. ${ }^{47}$ Dalam pelaksanaannya ia menafsirkan ayat tidak secara tekstual, melainkan difokuskan pada ajaran. Penafsiran tersebut dilakukan secara eksklusif berdasarkan manuskrip yang ada. Hal ini menunjukkan bahwa Jam 'iyah Sulukiyah mewakili bagaimana orang-orang kuno zaman dulu menafsirkan dan menghayati kandungan spiritual Al-Qur'an melewati gerakan-gerakan thariqah. Kegiatan semacam ini seperti yang dituturkan oleh K. Turmudzi Jaka menunjukkan bahwa jam'iyah tersebut menggambarkan bagaimana intensitas masyarakat Madura kelas bawah dalam berinteraksi dengan Al-Qur'an. ${ }^{48}$

Begitupula di daerah Paragaan, pengajian tafsir yang dipimpin oleh K. Fauzi ${ }^{49}$

\footnotetext{
${ }^{45}$ Mudhar Tamim, Tafsir al-Qur'an al-Karim Nurul Huda, h. viii.

${ }^{46}$ Islah Gusmian, Khazanah Tafsir Indonesia: Dari Hermeneutika hingga Ideologi, h. 176.

${ }^{47}$ Saat ini dipimpin oleh K. Sa'ad, mantan kepala desa Parenduan.

${ }^{48}$ Wawancara dengan K. Turmudzi Jaka pada hari Sabtu, 25 maret 2017. K. Turmudzi Jaka adalah putra dari Kiai Jamaluddin Kafie yang saat ini bergerak dibidang sastra di daerah Parenduan Sumenep. Ia mengasuh pesantren ad-Dzikir melanjutkan perjuangan ayahnya.

${ }^{49}$ Kiai Fauzi adalah pengasuh Pondok Pesantren al-Ihsan, salah satu ulama Madura yang tersohor karena kealimannya. Kiai yang sangat hati-hati dalam perkara syubhat, termasuk bantuan uang dari Negara. Apalagi dalam politik, ia memang tidak sama sekali terlibat di dalamnya. Beliau wafat pada tanggal 10 juli 2010. Keterangan ini diperoleh dari hasil wawancara dengan salah satu muridnya, Ach. Maimun, pada tanggal 18 Agustus 2017.
} 
merupakan pengajian Al-Qur'an biasa yang diterangkan dan dijelaskan maksud dari ayat yang dibaca dengan menggunakan bahasa Madura kepada masyarakat yang ikut pengajian tersebut. Pengajian ini berlangsung pada sekitar tahun 1980-an. Pelaksanaannya dimulai selepas shalat maghrib sampai isya'. Di samping itu, Kiai Fauzi juga mengadakan pengajian tafsir tersebut seminggu sekali, setiap selesai shalat jum'at di Masjid. Ada salah satu jama'ah yang memang sengaja menuliskan semua ayat al-Quran tersebut dan memberikan catatan sesuai dengan yang dijelaskan oleh kiai, namun naskah tersebut tidak dapat ditemukan saat ini. ${ }^{50}$

Akan tetapi ada sebagian yang merekam pengajian tersebut. Salah satunya pada saat membahas tentang surah al-Syu'ara: 132. Corak atau karakteristik penafsirannya adalah sufistik, dipengaruhi oleh keperibadiannya yang sangat tawadhu' dan zuhud. Misalnya:

Ben tako'ah been kappi dhe' ka dzat (Allah) se apareng nikmat, ropanah hewan; sapeh ontah, embi' jheren, ben potoh, ben kebun, somber se benyak.

Dalam bahasa Indonesia; "dan takutlah kalian semua kepada Allah yang telah memberi nikmat, berupa Hewan (sapi, kambing, kuda) dan anak-anak. Beserta kebun dan sumber yang banyak".

Dalam penjelasannya, ia mengisahkan tentang kaum Nabi Hud yang tidak percaya tentang nikmat yang telah diberikan oleh Allah. Mereka mengira bahwa nikmat tersebut sudah ada dengan sendirinya. Merasa bahwa dirinya kaya dan merasa lebih dari yang lain. Penjelasan ini dikaitkan dengan cerita tentang Nabi Muhammad yang menolak untuk dijadikan orang kaya. Bahkan Nabi ingin merasakan lapar sehari karena ingin mengetahui nikmatnya pahala sabar. Sedangkan pada saat kenyang dalam sehari, ia ingin merasakan pahalanya bersyukur. Nabi Muhammad ingin merasakan kenikmatan yang sesungguhnya pada saat di akhirat nanti, tidak dalam dunia saat ini. Pada intinya beliau menekankan tentang bagaimana hidup sederhana tidak terlalu memikirkan harta dan tahta. ${ }^{51}$

Pengajian yang seperti itu sebenarnya sama dengan karya tafsir al-Manar yang ditulis oleh Muhammad Abduh berdasarkan penjelasan dari gurunya, Rasyid Ridla, seandainya pengajian yang dilakukan oleh K. Fauzi tersebut ada yang membukukannya. Hal ini sempat dilakukan oleh K. Muhsin yang juga mengadakan pengajian tafsir di daerah Lenteng Barat setiap satu bulan sekali, meliputi banyak surah dalam Al-Qur'an. ${ }^{52}$ Akan tetapi yang sempat ditulis dan dikumpulkan hanyalah surat al-Fatihah yang akan menjadi salah satu objek pembahasan tafsir pada penjelasan selanjutnya.

Selain karya tafsir tersebut, ada sebagian tafsir-yang bisa dikategorikan tafsir awal-yang ditulis oleh ulama di Madura, tetapi manuskrip atau kitabnya hilang. Seperti syarah tafsir ash-Shabuni yang ditulis oleh Kiai Tidjani. Sebagaimana diungkapkan oleh Nyai Annisah, Istri Kiai Tidjani, kitab tafsir tersebut sempat menjadi materi tafsir

\footnotetext{
${ }^{50}$ Wawancara dengan K. Ach. Maimun pada tanggal 11 Maret 2017.

${ }^{51}$ Pengajian ini direkam pada tanggal 1 Mei 2009.

${ }^{52}$ Wawancara dengan K. Muhsin Amir pada hari Jum'at, 17 maret 2017. Beberapa yang sudah selesai diajarkan adalah surah al-Baqarah, dan surah Munjiyat.
} 
kelas VI Awwaliyah di Pondok Pesantren al-Amien. ${ }^{53}$ Selain itu, Kiai Jamaluddin Kafie, salah satu kiai yang cukup produktif di Parenduan, juga menulis kitab tafsir, yaitu tafsir al-Fatihah dan syarah tafsir fi dhilal al-Quran karya Sayyid Kutub. Akan tetapi seperti penuturan Kiai Turmudzi Jaka, putranya, kedua tafsir tersebut tidak ditemukan. ${ }^{54}$

\section{POTRET TAFSIR PADA ABAD KE-20 DI MADURA}

Dimulai pada tahun 1990-an hingga sekarang karya tafsir di Madura mulai bermunculan, dari berbagai jenis dan bentuk penafsiran. Mulai dari tafsir yang berkonsentrasi pada surah-surah tertentu, ayat dan tema tertentu, terjemah, hingga pada tafsir yang lengkap 30 juz. Secara keseluruhan ada lima belas literatur yang ditemukan dan sudah dicetak menjadi buku dan dipublikasikan untuk khalayak umum. Beberapa tafsir tersebut adalah; 1) Tafsir al-Asas; Kandungan dan Rahasia di Balik FirmanNya oleh K. Busyro, 2) Tafsir Yasin oleh K. Abd. Basith, 3) Tafsir Yasin oleh K. Munif Sayuthi, 4) Tafsir al-Fatihah oleh K. Muhsin Amir, 5) Jalan ke Surga; esai-esai Pernikahan dan keluarga oleh K. M. Musthafa, 6) Tafsir Firdaus al-Na'im bi Taudihi Ma'ani Ayat al-Quran al-Karim yang ditulis oleh Kiai Thaifur Ali Wafa. 7) Makanan Sehat dalam Al-Qur'an; Kajian Tafsir bi al-'Ilmi dengan Pendekatan Tematik ditulis oleh Nyai Fairuzah Tsabit, 8) Semiotika Kisah Al-Qur'an; Membedah Perjalanan Religi Raja Sulaiman dan Ratu Balqis oleh Fathurrosyid, 9) Setetes rahasia alam Tuhan melalui peristiwa metafisika al-mi'raj yang ditulis oleh KH. Bahauddin Mudhari, 10) Tafsir tradisionalis; membumikan teks dalam konteks kehidupan sosial yang ditulis oleh KH. A busyro Karim, 11) Tafsir al-Fatihah oleh K. Munif Sayuthi, 12) Tafsir al-Quran al-Karim oleh K.H. Ach. Basyir AS, 13) Tafsir al-Quran alKarim oleh K.H. Sa'di Amir, 14) al-Quran terjemah Bhasa Madhura yang disusun oleh Lembaga Penerjemah dan Pengkajian Al-Qur'an (LP2Q) Pamekasan, 15) alQuran al-Karim the Wisdom oleh K. M. Musthafa.

Dari ke-lima belas tafsir tersebut akan diklasifikasikan berdasarkan metodologinya, yang meliputi; bentuk, corak dan metode dari masing-masing tafsir tersebut:

\section{Bentuk}

Secara umum, penafsiran Al-Qur'an dapat dikategorikan menjadi dua bagian: tafsir bi al-ma'tsûr dan tafsir bi al-ra'yi. Tafsir bi al-ma'tsûr adalah tafsir yang bersumber dari Al-Qur'an, hadits, dan atsar sahabat. Sedangkan, tafsir bi al-ra'yi adalah tafsir yang berpegang terhadap ijtihad atau bersumber dari pendapat ulama salaf. ${ }^{55}$ Hal ini

${ }^{53}$ Wawancara dengan Nyai Annisah pada tanggal 29 Maret 2017. Selain itu juga wawancara kepada putranya, Kiai Fauzi Tidjani pada tanggal 15 Maret 2017.

${ }^{54}$ Wawancara dengan Kiai Turmudzi Jaka pada tanggal 02 April 2017.

${ }_{55}$ Muhammad Sayyid Thanthawi, Ulûm al-Qur'an (Jogjakarta: IRCiSoD, 2013), h. 140-143. Penjelasan yang sama, baca Mani' Halim Mahmud, Metodologi Tafsir (Jakarta: PT RajaGrafindo Persada, 2006), h. viii-ix; Manna' Khalil al-Qattan, Studi Ilmu-Ilmu Al-Qur'an (Bogor: PT. Pustaka Litera AntarNusa, 2002), h. 482-489. Selain tafsir bi al-ma'tsûr dan tafsir bi al-ra'yi, M. Quraish Shihab menambahkan tafsir isyâry (tafsir yang mengandalkan kesan yang diperoleh dari teks) sebagai bagian ketiga dalam pembagian tafsir. Lihat, M. Quraish Shihab, Kaidah Tafsir (Tangerang: Lentera Hati, 2013), h. 350. Baca juga Thameem Ushama, Metodologi Tafsir Al-Qur'an (Jakarta: Riora Cipta, 2000), h. 5. 
yang juga disebut oleh Nashruddin Baidan sebagai bentuk penafsiran yang dibagi menjadi dua bentuk ( $m a^{\prime}$ tsur dan $\left.r a^{\prime} y u\right) .{ }^{56}$

Dalam karya tafsir ulama di Madura tidak ditemukan tafsir yang berbentuk tafsir bi al-ma'tsur. Semuanya masuk dalam kategori bi al-ra'yi. Misalnya; tafsir tematik yang ditulis oleh K.H. Ach. Basyir as dan K. Ahmad Sa'di. Apalagi tafsir yang ditulis berdasarkan kepentingan akademik, seperti yang ditulis oleh Nyai Fairuzah dan Fathurrosyid. Kedua tafsir tersebut sangat kelihatan kinerja akal lebih dominan.

\section{Metode}

Menurut M. Quraish Shihab, metode penafsiran dibedakan menjadi empat macam: Pertama, analisis (tahlîlî), yaitu metode yang berusaha menjelaskan kandungan ayatayat Al-Qur'an dari berbagai seginya, sesuai dengan pandangan, kecenderungan, dan keinginan mufasirnya yang dihidangkannya secara runtut sesuai dengan perurutan ayat-ayat dalam mushaf. Kedua, global (ijmâlî), yaitu metode yang hanya menguraikan makna-makna umum yang dikandung oleh ayat-ayat yang ditafsirkan, namun sang penafsir diharapkan dapat menghidangkan makna-makna dalam bingkai suasana Qur'ani. Ketiga, perbandingan (muqârin), yaitu metode yang membandingkan penafsiran satu ayat atau lebih antara seorang mufasir dengan mufasir yang lain. Keempat, tematik (mawdh $\hat{u}$ ' $)$, yaitu metode yang mengarahkan pandangan kepada satu tema tertentu, lalu mencari pandangan Al-Qur'an tentang tema tersebut dengan jalan menghimpun semua ayat yang membicarakannya, menganalisis, dan memahaminya ayat demi ayat, menghimpunnya dalam benak ayat yang bersifat umum, yang muthlaq digandengkan dengan yang muqayyad, dan lain-lain, sambil memperkaya uraian dengan hadits-hadits yang berkaitan untuk kemudian disimpulkan dalam satu tulisan pandangan menyeluruh dan tuntas menyangkut tema yang dibahas itu. ${ }^{57}$

Dari keempat metode tersebut, yang masuk pada metode ijmali ada tiga tafsir, yaitu 1) tafsir tematik yang ditulis oleh K.H. Ach. Basyir AS, 2) Tafsir tematik yang ditulis K. Ahmad Sa'di, dan 3) Al-Qur'an Terjemah Bhasa Madhura. Sedangkan metode tahlili ada enam tafsir, yaitu diwakili oleh karya tafsir pada surah-surah tertentu; 1) Tafsir al-Fatihah oleh K. Busyro, 2) Tafsir Yasin oleh K. Abd. Basith, 3) Tafsir Yasin dan 4) Tafsir al-Fatihah oleh K. Munif Sayuthi, 5) Tafsir al-Fatihah oleh K. Muhsin Amir, ditambah dengan 6) Tafsir Firdaus al-Na'im bi Taudihi Ma'ani Ayat al-Quran al-Karim yang ditulis oleh Kiai Thaifur Ali Wafa. Sedangkan Sisanya, termasuk pada metode maudhu'i (tematik), yaitu; 1) Makanan Sehat dalam Al-Qur'an; Kajian Tafsir bi al-'Ilmi dengan Pendekatan Tematik ditulis oleh Nyai Fairuzah Tsabit, 2) Semiotika Kisah Al-Qur'an; Membedah Perjalanan Religi Raja Sulaiman dan Ratu Balqis oleh Fathurrosyid, 3) Jalan ke Surga; esai-esai Pernikahan dan keluarga serta 4) Al-Qur'an al-Karim the Wisdom oleh K. M. Musthafa, 5) Tafsir Tradisionalis; membumikan teks dalam konteks kehidupan sosial oleh KH. A. Busyro Karim, 6) Setetes rahasia alam Tuhan melalui peristiwa metafisika al-Mi'raj oleh KH. Bahauddin Mudhary.

${ }^{56}$ Nashruddin Baidan, Rekonstruksi Ilmu tafsir, Pidato Pengukuhan Guru Besar Madya Ilmu Tafsir, (Surakarta, STAIN Surakarta, 1999), h. 17-18.

${ }^{57}$ M. Quraish Shihab, Kaidah Tafsir, h. 378-385. 


\section{Corak}

Sedikitnya terdapat 3 macam corak yang banyak dipakai oleh para Mufassir abad pertengahan. Antara lain tafsir dengan corak fiqhi atau legalistik (fiqh oriented), corak sektarian (madzhaby), dan corak sufistik (tasawwuf). Selain dari ketiganya, corak Isyari, corak 'ilmi, corak adabi ijtima'I (social), dan corak lughawî (kebahasaan/ language) adalah macam corak baru yang diperkenalkan oleh Mufassir-mufassir kontemporer seperti Thanthawi Jauhari dengan karyanya yang bercorak tafsir ilmi, Tafsir al-Jawahir fi Tafsir al-Qur'an. Juga tafsir dengan memakai corak tafsir teologi yang digunakan oleh Zamakhsyari dalam bukunya Tafsir al-Kasysyaf. ${ }^{58}$

Pemilihan corak mayoritas dipengaruhi oleh basic keilmuwan dari si Pengarang. Contoh paling mudah adalah tafsir karya Imam Syafi'I yang bernama Tafsir al-Imam al-Syafi'i. Imam Syafi'I adalah salah satu dari Imam yang menjadi panutan mayoritas umat Islam Asia dalam hal fiqih atau dimensi syari'ah. Dalam tafsir yang dikarangnya, beliau fokus menafsirkan hanya sebatas pada ayat yang berkaitan dengan hukum syari'ah. Di luar ayat al-ahkam beliau tidak menafsirkannya.

Sebenarnya dalam satu tafsir bisa saja seorang mufassir memakai banyak corak. Misal jika ayat tersebut berkaitan dengan al-ahkam maka mufassir bisa menggunakan corak fiqhi. Sedangkanjika bertemu dengan ayat kauniyah mufassir beralih menggunakan corak 'ilmi. Perpaduan ini bertujuan supaya hasil tafsir bisa maksimal. Salah satu contoh tafsir tematik yang ditulis oleh K.H. Ach Basyir AS yang menggunakan corak fiqhi dan 'ilmi. Sedangkan yang lain dominan pada satu corak tafsir saja. Misalnya Tafsir Firdaus al-Na'im bi Taudihi Ma'ani Ayat al-Quran al-Karim yang ditulis oleh Kiai Thaifur Ali Wafa menggunakan corak lughawi. Tafsir yasin K.H. Abd. Basit AS menggunakan corak adabi ijtima'ie, dan tafsir Nyai Fairuzah tentang makanan sehat dalam Al-Qur'an menggunakan tafsir corak ilmi, dll. Untuk mempermudah dalam memahami periodisasi dan metodologi penulisan tafsir di Madura, perhatikan tabel berikut:

\begin{tabular}{|c|c|c|c|c|c|c|}
\hline \multirow{2}{*}{ No } & \multirow{2}{*}{ Periode } & \multirow{2}{*}{ Literatur Tafsir } & \multirow{2}{*}{ Mufasir } & \multicolumn{3}{|c|}{ Metodologi } \\
\hline & & & & Bentuk & Metode & Corak \\
\hline 1 & $\begin{array}{c}\text { Masa } \\
\text { Kelahiran } \\
\text { (Akhir abad } \\
\text { ke-19) }\end{array}$ & Tafsir antar baris & $\begin{array}{l}\text { Syaikhona } \\
\text { Khalil }\end{array}$ & Ro’yu & Ijmali & Lughawi \\
\hline \multirow{2}{*}{2} & \multirow{2}{*}{$\begin{array}{c}\text { Masa } \\
\text { Pertumbuhan } \\
\text { (pertengahan } \\
\text { abad ke-20) }\end{array}$} & $\begin{array}{l}\text { Tafsir Quran al- } \\
\text { Karim Nurul Huda }\end{array}$ & $\begin{array}{l}\text { Kiai } \\
\text { Mudhar } \\
\text { Tamim. }\end{array}$ & Ro’yu & Tahlili & $\begin{array}{l}\text { Adabi } \\
\text { ijtima'ie } \\
\text { \& fiqhi }\end{array}$ \\
\hline & & The oral interpretation & $\begin{array}{l}\text {-Kiai Fauzi } \\
\text {-Jam'iyah } \\
\text { Sulukiyah }\end{array}$ & - & - & - \\
\hline
\end{tabular}

${ }^{58}$ Rosihon Anwar, Pengantar Ulumul Qur'an h.196-197.

88 | Al-Fanar: Jurnal Ilmu Al-Qur'an dan Tafsir 
Ulfatun Hasanah

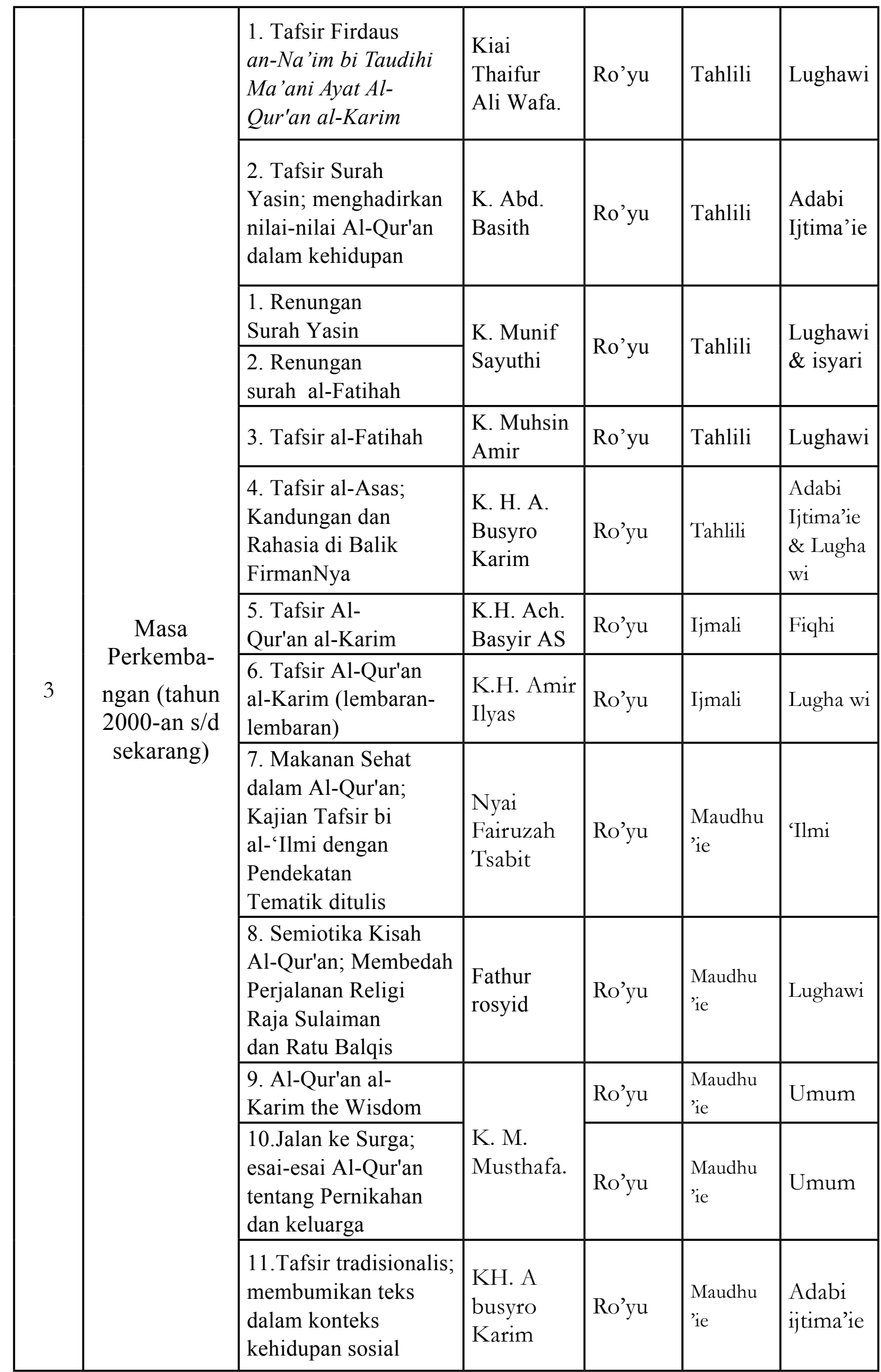




\begin{tabular}{|l|l|l|l|l|l|l|}
\hline & $\begin{array}{l}\text { 12. Setetes rahasia } \\
\text { alam Tuhan } \\
\text { melalui peristiwa } \\
\text { metafisika al-mi'raj }\end{array}$ & $\begin{array}{l}\text { KH. } \\
\text { Bahauddin } \\
\text { Mudhari }\end{array}$ & Ro'yu & $\begin{array}{l}\text { Maudhu } \\
\text { 'ie }\end{array}$ & 'Ilmi \\
\cline { 2 - 6 } & $\begin{array}{l}\text { 13.Al-Quran terjemah } \\
\text { bahsa Madura }\end{array}$ & LP2Q & Ro'yu & Ijmali & Umum \\
\hline
\end{tabular}

Dari tabel diatas dapat diketahui bahwa seluruh karya tafsir di Madura terdapat dua puluh karya, yakni dengan perincian delapan belas karya dalam bentuk naskah dan dua lainnya penafsiran lisan (tidak dibukukan). Sedangkan dari segi Metodoligi nya, bentuk yang digunakan secara keseluruhan adalah tafsir bi al-ra'yi. Metode ijmali terdapat empat, tahlili tujuh, dan maudhu'ie enam. Coraknya yang lughawi ada lima, adabi ijtima'ie dua, fiqhi satu, ilmi ada dua karya, dan yang campuran (lebih dari satu corak) terdapat tiga karya.

\section{PENUTUP}

Dari pembahasan di atas dapat disimpulkan bahwa, pertama, persinggungan masyarakat Madura dengan Al-Qur'an, mulai sejak islamisasi awal, dimulai dengan pengajaran Al-Qur'an di Langgar-langgar (Mushalla), pengajian dalam perkumpulan kelompok-kelompok keagamaan, hingga kepada penulisan kitab-kitab tafsir, baik tematik surah maupun tafsir yang lengkap 30 juz seperti yang ditulis oleh KH. Thaifur Ali Wafa yang berjudul Firdaus al-Na'im bi Taudih al-Ma'ani ayat al-Quran alKarim. Kedua, mengenai geneologi tafsir di Madura dimulai dari ditemukannya AlQur'an terjemah karya Syaikhona Khalil - episentrum (kiblat) bagi para Ulama dan pengasuh Pesantren di Nusantara-pada akhir abad ke-19, kira-kira tahun 1900-an. Pada dasarnya karya tersebut sebatas menerjemahkan makna perkata dari Al-Qur'an yang ditulis oleh kakek buyutnya, Syekh Abdul Karim. Tulisannya menggunakan huruf pegon dengan berbahasa Madura. Dari uraiannya terlihat sangat kental dengan qawaid bahasa Arab atau I'rab, karena Syaikhona Khalil memang ahli di bidang gramatika bahasa arab (Nahwu).

\section{DAFTAR PUSTAKA}

Abdurachman. Sejarah Madura. Sumenep: Offset Matahari, 1988.

Akhmad, Bendara. Lintasan Sejarah Sumenep dan Asta Tinggi Beserta Tokoh di dalamnya. Sumenep, Barokah, 2011.

Arrifai, Ibnu Assayuthi. Korelasi Syaikhona Kholil Bangkalan dan NU. Cirebon: Al Haula Press. 2010.

Azis, Ali. "Negeri Mullah, Negeri Beribu Kisah", AULA Majalah Nahdlatul Ulama, Vol. XXXI, Nomor 11 November 2009.

Azmatkan, Ali, bin Badri. Dari Kanjeng Sunan Sampai Romo Kiai Syaikhona Muhammad Khalil Bangkalan: Telaah Sejarah dan Riwayat Hidup. Bangkalan: Ikazi, 2007.

Azra, Azyumardi. Renaisans Islam Asia Tenggara. Bandung: Remaja Rosdakarya, 1999. . Jaringan Ulama; Timur Tengah dan Kepulauan Nusantara Abad XVII dan XVIII. Bandung: Mizan, 1999. 
Baidan, Nashruddin. Rekonstruksi Ilmu tafsir, Pidato Pengukuhan Guru Besar Madya Ilmu Tafsir. Surakarta, STAIN Surakarta, 1999.

Al-Bantany, Muhammad Nawawi. Marâh Labîd Tafsîr al-Nawawî. t.tp: al-Maktabah al-Uthmânîyah, 1305. Bizawie, Zainul Milal. Masterpiece Islam Nusantara, Sanad dan Jejaring Ulama-Santri (1830-1945). Ciputat: Pustaka Kompas, 2016.

Bruneissan, Martin Van. Kitab Kuning, Pesantren dan Tarekat. Yogyakarta: Gading Publishing, 2012.

Graaf, H.J. Puncak Kekuasaan Mataram. Jakarta: Grafitipress 1986.

Gusmian, Islah. Khazanah Tafsir Indonesia; dari Hermeneutika hingga ideology. Yogyakarta: LKis, 2013.

Imron, Fuad Amin. Syaikhona Khalil Bangkalan, Penentu Berdirinya Nahdlatul Ulama. Surabaya: Khalista, 2012.

Jauhari, Muhammad Tidjani (ed. Hamzah Arsa). Membangun Madura. Jakarta: Taj Publishing, 2008.

Jonge, Huub de. Madura dalam Empat Zaman Pedagang, Perkembangan Ekonomi dan Islam. Jakarta: Gramedia, 1989.

Kosim, Mohammad. "Langgar sebagai Institusi Pendidikan Keagamaan Islam", Tadris Jurnal Pendidikan Islam, Volume 4. Nomor 2 th 2009.

Kuntowijoyo. Perubahan Sosial dalam Masyarakat Agraris: Madura 1850-1940. Yogyakarta: Matabangsa, 2002.

Mahmud, Mani’ Halim. Metodologi Tafsir. Jakarta: PT RajaGrafindo Persada, 2006.

Mansurnoor, Iik Arifin. Islam in an Indonesian World, Ulama of Madura. Yogyakarta: Gadjah Mada University Press, 1990.

Al-Qattan, Manna' Khalil. Mabahits fi Ulum al-Quran, Terj. Muzakkir As. Bogor: Litera Antar Nusa, 1996.

Rahman, Saifur. Biografi dan Karomah Kiai Khalil Bangkalan, Surat Kepada Anjing Hitam. Jakarta: Pustaka Ciganjur, 2001.

Sadik, A. Sulaiman. Sangkolan: Legenda ban Sajara Madhura. Pamekasan: Pemerintah Kabupaten Pamekasan, 2006.

Shihab, M. Quraish. Kaidah Tafsir. Ciputat, Lentera Hati, 2015.

Al-Silmi, Abu Isa Muhammad bin Isa al-Turmudzi. Sunan al-Turmudzi. Beirut: Dar ihya' al-Turas al-Arabi, tt. Steenbrink, Karel A. Beberapa Aspek tentang Islam di Indonesia abad ke-19. Jakarta: Bulan Bintang, 1984.

Sunyoto, Agus. Wali Songo, Rekonstruksi Sejarah yang Dihilangkan . Jakarta: Trans Pustaka, 2011

Tamim, Mudhar. Tafsir al-Quran al-Karim Nurul Huda. Surabaya: tp, 1969.

Thanthawi, Muhammad Sayyid. Ulum Al-Qur'an. Jogjakarta: IRCiSoD, 2013.

Ushama, Thameem. Metodologi Tafsir Al-Qur'an. Jakarta: Riora Cipta, 2000.

Wardi, Moh. "Pilihan Belajar Al-Quran di Madura: Konversi dari Langgar ke Taman Pendidikan al-Quran” Jurnal Kabilah, Vol. 1 No. 1 Juni 2016. 
Sejarah dan Perkembangan Penulisan Tafsir Al-Quran di Madura

Wiyata, A. Latief. Carok: Konflik Kekerasan dan Harga Diri Orang Madura. Yogyakarta: LKIS, 2003.

Zulkarnain, Iskandar. Sejarah Sumenep. Sumenep: Dinas Pariwisata dan Kebudayaan Kabupaten Sumenep, 2003.

92 | Al-Fanar: Jurnal Ilmu Al-Qur'an dan Tafsir 